\title{
Tax Reform and Automatic Stabilization
}

\author{
Thomas J. Kniesner \\ Department of Economics \\ and \\ Center for Policy Research \\ Syracuse University \\ and \\ James P. Ziliak \\ Department of Economics \\ University of Oregon
}

January 2000

* Address Correspondence to: Thomas J. Kniesner, Center for Policy Research, 426 Eggers Hall, Syracuse University, Syracuse, NY 13244-1020; phone: (315) 443-4589; Email: TKniesne@ Maxwell.Syr.Edu. We thank Alan Auerbach, John Kennan, Frank Wolak, and seminar participants at Stanford University for comments on an earlier draft. All errors are our own. 


\title{
Tax Reform and Automatic Stabilization
}

\begin{abstract}
A fundamental property of a progressive income tax is that it provides implicit collective insurance against idiosyncratic shocks to income by dampening the variability of disposable income and consumption. The Economic Recovery Tax Act of 1981 (ERTA) and the Tax Reform Act of 1986 (TRA86) greatly reduced the number of marginal tax brackets and the maximum marginal rate, which limits the ability of households to stabilize consumption in the face of transitory fluctuations in taxable income. We examine the effect of the federal income tax reforms of the 1980s on the associated degree of automatic stabilization of consumption. The empirical framework derives from the consumption insurance literature where the ideal outcome is spatially equal changes in households' marginal utilities of consumption. Because evidence for U.S. households rejects complete consumption insurance we begin with a model of partial consumption insurance, which we use to identify how the degree of partial insurance has changed since ERTA and TRA86. Our data come from interview years 1980-1991 in the Panel Study of Income Dynamics. Although in some cases the tax reforms of the 1980s actually increased the automatic stabilization inherent in a progressive income tax (especially when the Social Security payroll tax and the Earned Income Tax Credit are included), our overall outcome is that ERTA and TRA86 reduced consumption stability by about 50 percent. More recent tax reforms, most notably increased EITC generosity, have restored or enhanced consumption insurance.
\end{abstract}

Keywords: Consumption Insurance, Transitory Income, Progressive Income Taxes, Earned Income Tax Credit, Forward-Filter Estimator 
One of the most important economic events of the 1980s was the comprehensive overhaul of the U.S. federal income tax system. The Economic Recovery Tax Act of 1981 (ERTA) reduced marginal tax rates an average of 23 percent within each bracket. The Tax Reform Act of 1986 (TRA86) broadened the tax base and reduced the number of tax brackets from 16 to two. The top marginal tax rate dropped from 70 percent in 1981 to 50 percent in 1982 then to 28 percent in 1988 . In 1980 over 75 percent of taxpayers faced statutory tax rates above 15 percent; by 1995 less than 25 percent faced rates above 15 percent (Burman et al. 1998). Overall, the tax reforms in the 1980s reduced the average tax burden by 25 percent. Many economists have examined how tax reform influenced incentives to work (Blundell et al. 1998, Bosworth and Burtless 1992, Eissa 1996, Kniesner and Ziliak 1998, Ziliak and Kniesner 1999), to save (Bernheim 1999, Bosworth and Burtless 1992, Engen and Gale 1996), and to invest (Auerbach 1996, Auerbach and Slemrod 1997). Conspicuously absent is research on how the tax reforms of the 1980s reduced a beneficial aspect of progressive taxation, the so-called automatic stabilizer. We examine empirically how the reforms of the federal income tax in the United States during the 1980s reduced the automatic smoothing of disposable income and consumption after a shock to income.

The lack of research on automatic stabilization is somewhat surprising because of the parallel literature on the consumption smoothing benefits of social insurance programs (Hamermesh 1982; Gruber 1996, 1997; Dynarski and Gruber 1997) and because a key function of a progressive income tax is to provide collective insurance against idiosyncratic shocks to income and in turn to smooth consumption and dampen the business cycle. In the face of a negative shock to taxable income, consumption is 
reduced by less because the tax burden is reduced as the household falls into a lower marginal tax bracket. However, with lower rates and fewer and wider marginal tax brackets under ERTA and TRA86 the likelihood of falling into a lower tax bracket after a negative shock is diminished, which limits households' ability to maintain consumption. Contrary to the welfare-enhancing effects of the flattening of the income tax in the 1980s operating through the incentive to supply labor (Hausman 1981, Kniesner and Ziliak 1998), a weakened automatic stabilizer is welfare-reducing because households have greater variability of disposable incomes (Varian 1980).

There is substantial empirical research on how actions within families (Hayashi, Altonji, and Kotlikoff 1996) and between families (Altug and Miller 1990, Attanasio and Davis 1996, Banks et al. 1997, Cochrane 1991, Deaton 1997, Gertler and Gruber 1997, Hayashi, Altonji, and Kotlikoff 1996, Mace 1991, Nelson 1994, and Townsend 1994) can stabilize consumption. The recent implicit consumption insurance research shares a common theoretical framework where a hypothetical central planner allocates resources across households to equate the growth rates of the marginal utility of consumption. The strong testable implication of complete consumption insurance is that the growth of each household's consumption should not depend on changes in the household's economic resources given the change in aggregate resources. With few exceptions (Altug and Miller 1990, Mace 1991), empirical research rejects complete implicit consumption insurance. A progressive income tax produces partial implicit consumption insurance for households when income changes unexpectedly. There is little research on partial implicit consumption insurance; most of it focuses on developing countries (Deaton 1997, Gertler 
and Gruber 1997), and little of it considers recent U.S. tax reforms (Auerbach and Feenberg 1999, Cohen and Follette 1999).

We specify a model of partial insurance where the focus is on identifying the degree to which partial consumption insurance has changed because of ERTA and TRA86. To track time variation in partial risk sharing we use panel data and the Keane and Runkle (1992) forward-filter estimators of Euler equations with latent heterogeneity. Our data are from the Panel Study of Income Dynamics (PSID) for interview years 1980_ 1991, which encompasses the periods before ERTA and after TRA86. Although food consumption is the measure examined most often by researchers using the PSID to test complete consumption insurance (Altug and Miller 1990, Cochrane 1991, and Hayashi, Altonji, and Kotlikoff 1996), it is plausible that the tax reforms of the 1980s did little to food consumption, which is stabilized by the Food Stamp Program. Instead, we use a measure of composite consumption constructed as a residual of income net of taxes and saving (Ziliak 1998).

We find that across the 1980s the progressive income tax stabilized consumption by 15 percent in response to a given reduction in gross income. On balance the tax reforms of the 1980s cut in half the stabilizing effect of the progressive income tax. There are some exceptions. Due largely to changes in Social Security taxes and the Earned Income Tax Credit consumption was increasingly stabilized during the 1980s for lowincome couples and single mothers in the upper half of the female-head income distribution. 


\section{Conceptual Framework}

The theory of complete consumption insurance begins with a social planner who, given household-specific social weights, $\mu^{k}$, allocates resources under uncertainty across households and over time to equalize the growth rates of the marginal utilities of consumption. More formally, the planner's problem is to maximize the weighted sum of households' utilities, or

$$
\operatorname{Max} \sum_{h=1}^{H} \mu^{h} \sum_{t=1}^{T} \sum_{s=1}^{S}\left(\rho^{h}\right)^{t} \pi_{s t} U\left(c_{s t}^{h}, \delta_{s t}^{h}\right)
$$

where $h$ indexes households, $t$ indexes time, $s$ indexes economic state, $\rho^{h}$ is the household's rate of time preference, $\pi_{s t}$ is the probability of state $s$ in time $t, c_{s t}^{h}$ is the household's consumption in state $s$ and time $t$, and $\delta_{s t}^{h}$ indexes shocks to preferences across households and over time. The resource constraint on the maximization problem posed is

$$
\sum_{h=1}^{H} c_{s t}^{h} \leq C_{s t}
$$

which implies that the sum of households' consumption expenditures cannot exceed aggregate consumption in state $s$ and time $t$.

The choice variable is household consumption, $c_{s t}^{h}$, and the first-order conditions for maximizing (1) subject to (2) are

$$
\left(\rho^{h}\right)^{t} \mu^{h} \pi_{t} U_{c}\left(c_{t}^{h}, \delta_{t}^{h}\right)=\lambda_{t}
$$

where $\lambda_{t}$ is the Lagrange multiplier associated with the resources constraint, and $U_{c}$ is the marginal utility of consumption. Notice that we drop the subscript $s$ because only one 
state is realized at time $t$. Taking the natural log of both sides of (3), first differencing to eliminate the fixed household social weight $\mu^{h}$, and rearranging yields

$$
\Delta \ln U_{c}\left(c_{t}^{h}, \delta_{t}^{h}\right)=\Delta \ln \lambda_{t}-\Delta \ln \pi_{t}-\ln \rho^{h} .
$$

Equation (4) contains the key prediction of complete consumption insurance, which is that the discounted growth in the marginal utility of consumption is constant across households, so that given aggregate resources, changes in individual households' resources do not affect how the marginal utility of consumption evolves.

To make equation (4) operational we need to specify a functional form for within period utility. We use the isoelastic utility function suggested by Deaton (1997)

$$
U\left(c_{t}^{h}, \delta_{t}^{h}\right) \equiv U\left(c_{t}^{h}, \theta_{t}^{h}, \sigma\right)=(1-\sigma)^{-1} \theta_{t}^{h} n_{t}^{h}\left(c_{t}^{h} / n_{t}^{h}\right)^{(1-\sigma)},
$$

where $\theta_{t}^{h}$ is an unobservable taste shifter that captures time variation in the household's preferences, $\sigma$ is the coefficient of relative risk aversion, $n_{t}^{h}$, is the size of household $h$ at time $t$, and $c_{t}^{h} / n_{t}^{h}$ is per capita consumption. Given isoelastic preferences equation (4) becomes

$$
\Delta \ln \left(c_{t}^{h} / n_{t}^{h}\right)=-\sigma^{-1}\left(\Delta \ln \lambda_{t}^{*}-\Delta \ln \theta_{t}^{h}-\ln \rho^{h}\right)=-\sigma^{-1}\left(\Delta \ln \lambda_{t}^{*}-\Delta \varepsilon_{t}^{h}\right) .
$$

Treating preference shocks as mean zero stochastic disturbances, the growth of per capita consumption will be the same for all households.

The model in (6) is the prototypical specification for testing the complete consumption insurance hypothesis. A substantial literature has emerged over the past decade testing the complete insurance hypothesis using data from developing countries (Deaton 1997, Gertler and Gruber 1997, Morduch 1995, Townsend 1994) as well as developed countries (Altug and Miller 1990, Attanasio and Davis 1996, Banks et al. 
1997, Cochrane 1991, Hayashi et al. 1996, Mace 1991, Nelson 1994). The consensus from the implicit consumption insurance literature is a resounding rejection of complete consumption insurance. Perhaps the rejection of complete insurance is not surprising given the attendant moral hazard problems inherent in devising such comprehensive insurance schemes. At the same token, high-frequency co-movements in the relative wage and consumption distributions strongly reject the extreme alternative of no consumption smoothing (Attanasio and Davis 1996). Institutions, both public and private, do exist to offset consumption loss because of income loss. A more general approach to examining consumption insurance empirically admits partial consumption insurance, whose effectiveness may vary over time.

\section{A. The Income Tax as Partial Insurance}

Consider the U.S federal income tax system and the attendant reforms in the 1980s. If the only tradeoff facing policymakers is between the equity effects of changing the income distribution and the efficiency cost of reduced incentives, then the optimal income tax literature predicts either a zero marginal income tax on the highest income earner (Stiglitz 1987) or a U-shaped marginal tax rate structure (Diamond 1998).

However, if policymakers are also concerned about the variability of after-tax income and consumption, and some of the observed differences in income are due to exogenous differences in "luck," then the marginal tax rate on the highest income earner might be quite large (Varian 1980; Strawczynski 1998). If redistribution and partial insurance are important policy objectives then a steeply progressive income tax system might provide beneficial collective insurance against idiosyncratic shocks to income and in turn smooth consumption. 
[Table 1 here]

In Table 1 we present the U.S. federal tax rates for a married couple filing jointly for one year before and after ERTA (1980 and 1982), and one year before and after TRA86 (1985 and 1987). The pre-ERTA U.S. federal income tax system is targeted heavily towards redistribution and partial insurance. In 1980 there were 16 marginal tax rates, which increased by about 4 percentage points for each successive bracket above the zero bracket amount. At low levels of the taxable income distribution the tax brackets were quite narrow, suggesting a high probability of tax-rate reduction in the event of an idiosyncratic income loss. ERTA did little with respect to the number and width of tax brackets, as evidenced by the rate schedules for 1982 and 1985, but ERTA did index the brackets for inflation by 1985 and reduced the marginal tax rates at all levels, especially for upper-income Americans. TRA86, however, slashed the number of statutory brackets to five in 1987 and to only two in 1988 (aside from the 33 percent "bubble" faced by some higher-income taxpayers). In addition, the brackets were widened substantially, which reduces the probability of a tax-rate reduction in the presence of income loss. Changes to the U.S. federal income tax code in the 1980s suggest a reduced concern about the automatic stabilizing component of the system relative to the deadweight loss of reduced incentives. Indeed, the 1982 and 1987 issues of the Economic Report of the President contained extensive discussion of the efficiency costs of high income tax rates had but no mention of the possible efficiency benefits via consumption smoothing. An intuitive way to think about the partial-insurance capability of the federal income tax is through the curvature of the tax function. To facilitate intuition we graph the statutory rates for 1980 and 1987 in Figure 1. It appears that that the pre-ERTA 
system is more globally concave than the post-TRA86 rate structure; that is, the rate of change in marginal tax rates is greater overall before ERTA than after TRA86. However, the 1987 structure appears more locally concave, particularly in the 15 to 28 percent marginal tax brackets. If the bulk of taxpayers are located just above the 28 percent tax kink, then automatic stabilization will have actually increased with TRA86. In 1995 about 60 percent of taxpayers were in the 15 percent bracket, and about 17 percent were in the 28 percent bracket (Burman et al. 1998). Provided that the incomes of upperincome Americans are relatively rigid downward, automatic stabilization would likely have decreased with TRA86.

\section{[Figure 1 here]}

Concurrent with the reforms to the federal income tax were reforms to the Social Security payroll tax (FICA) in the early 1980s and the Earned Income Tax Credit (EITC) with TRA86. Because of concerns over the solvency of the Social Security program, Congress legislated an aggressive program to increase both the FICA tax base and tax rates. During 1980-1987 the FICA tax base increased by 70 percent from $\$ 25,900$ to $\$ 43,800$, while the payroll tax rate increased by 17 percent from 6.13 to 7.15 percent. Simultaneously, to counter the regressivity of the payroll tax and to stimulate work among low-income households, Congress expanded the EITC in 1986 by increasing the phase-in subsidy rate from 10 percent in 1980 to 14 percent in 1987 and by decreasing the phase-out rate from 12.5 percent to 10 percent. The declining phase-out tax rate resulted in a 54 percent increase in the cut-off income level for credit eligibility from $\$ 10,000$ to $\$ 15,432$. Collectively, reforms to Social Security and the EITC likely offset to 
some extent the declines in federal marginal tax rates for low and moderate-income earners and may have restored the implicit automatic stabilization in the tax system.

To estimate how the partial consumption insurance implicit in the U.S. income tax system evolved during the 1980s the proportionate change in per capita consumption in equation (6) becomes

$$
\Delta \ln \left(c_{t}^{h} / n_{t}^{h}\right)=\alpha \Delta \ln \left(C_{t}\right)+\beta \Delta \ln \left(y_{d t}^{h}\right)+\Delta \varepsilon_{t}^{h},
$$

where aggregate consumption, $C_{t}$, represents aggregate resource constraints at time $t$, and $y_{d t}^{h}$ is the household's time $t$ disposable income, $y_{d t}^{h} \equiv y_{t}^{h}-T\left(y_{t}^{h}-E_{t}^{h}-D_{t}^{h}\right)+\underline{C}_{t}^{h}\left(y_{t}^{h}\right)$. Total tax payments, $T(\cdot)$, are a function of taxable income defined as gross income less exemptions and deductions, and credits, $\underline{C}(\cdot)$, are a function of gross income. The complete consumption insurance hypothesis is that $\beta=0$ in the cross section, but under partial insurance consumption changes will be a function of both aggregate and idiosyncratic resources. With an effective partial insurance mechanism the impact of a gross-income change on a per capita consumption change is $\beta\left(1-\tau_{t}^{h}\right) \frac{y_{t}^{h}}{y_{d t}^{h}}$, where $\tau_{t}^{h}$ is the household's marginal tax rate.

\section{Data}

Our data come from the Panel Study of Income Dynamics (PSID) for interview years 1980-1991. Because the survey has followed the same core households since 1968, plus newly formed households as members of the original core have split off into new families, the PSID contains detailed information on income and household composition. Our data span the two major recent income tax reforms in the United States, which occurred in 1981 (ERTA) and 1986 (TRA86), and are the best available to study how a 
less graduated income tax affected the automatic stabilization that is a byproduct of a progressive income tax.

Our sample is an unbalanced panel that treats missing observations as random events and only eliminates a missing person year of data so that the time series for different households can be of different length within 1980-1991. To be included in the sample the household head (1) must be at least 25 in 1980 and no more than 64 in 1991, (2) must be finished with schooling by 1980, (3) cannot be permanently disabled or institutionalized, and (4) must have the same marital status for 1980-1991 so as to keep the same tax table, which facilitates understanding how taxpayers who income split with a spouse for tax purposes may be differentially affected by the tax reforms of the 1980s. In addition to requiring continuous marital status, to reduce further the influence of major compositional changes and possible outliers we follow the previous consumption literature and delete person-years with a more than 300 percent increase or a 75 percent decrease in consumption. We also require per capita consumption and disposable income to be no less than $\$ 1000$ in any year. Our selection criteria produce a sample of 1298 households and 11,043 person years.

The advantage of the PSID relative to repeated cross-section surveys such as the Consumer Expenditure Survey (CEX) is that the PSID follows the same households longitudinally, which makes it unnecessary to construct time series on artificial households based on membership in demographic cohorts (Attanasio and Davis 1996). The disadvantage of the PSID is that it presents less ideal measures of consumption than the CEX. Previous studies using the PSID to test for complete consumption insurance examine Euler equations for food consumption expenditures (Altug and Miller 1990, 
Cochrane 1991, Hayashi, Altonji, and Kotlikoff 1996). For comparability we too estimate Euler equations for food expenditures. Because tests of the permanent income hypothesis are known to be sensitive to the consumption measure, our focus is on a broader measure of consumption defined as the residual of income net of the change in wealth and taxes paid (Ziliak 1998).

To elaborate on the more comprehensive consumption measure we use, the PSID allows one to estimate household wealth $\left(A_{t}^{h}\right)$ alternatively as liquid assets (the capitalized value of rent, interest, and dividend income) or the sum of liquid assets and home equity (the difference between house value and mortgage principal). Given a measure of wealth, personal saving is the year-to-year change in wealth, $S_{t}^{h}=A_{t+1}^{h}-A_{t}^{h}$. Composite consumption then follows by subtracting saving from disposable personal income, $C_{t}=y_{d t}^{h}-S_{t}$. Although Ziliak (1998) focuses on the broader wealth measure, most of the flow in saving emanates from liquid sources. Moreover, it may be tenuous to define consumption as involving unrealized capital gains in the housing stock. Most of our tests rely on the narrower definition of consumption based on liquid wealth.

For our automatic-stabilization tests the composite consumption measure is advantageous because food expenditures are likely to be primarily stabilized by the Food Stamp Program. An unfortunate data problem also limits the usefulness of food consumption; the PSID did not collect food consumption for the 1988 and 1989 interview years, which are two critical years after TRA86 needed to identify automatic stabilization effects. Our composite consumption measure also improves on a predicted consumption measure for the PSID proposed by Skinner (1987) because Skinner's measure may be 
inaccurate if the relative prices of goods change (Attanasio and Weber 1995). ${ }^{1} \mathrm{~A}$ potential disadvantage of our consumption measure is that it implicitly includes durable goods, which introduces the difficulty of distinguishing between expenditures and service flows of consumption (Hayashi 1985). Hayashi includes durable consumption by modeling total consumption as a distributed lag of current and previous expenditures. Although we do not take the distributed lag approach for the evolution of consumption, we do attempt to control for implied autocorrelation in our composite consumption measure via our econometric estimator soon described below. We believe that the advantages of our residual based consumption measure over food consumption and Skinner's consumption measure are sufficient even in light of the amalgamation of durable and non-durable expenditures.

The final data issue we need note concerns key independent variables in our estimating equation (7); namely, gross family income and tax payments. Information is available to construct family income from labor and interest earnings and transfers received. Because transfer income such as unemployment insurance, food stamps, and AFDC is an important source of consumption insurance (Hamermesh 1982, Dynarski and Gruber 1997, Gruber 1996, 1997) we include government transfers as part of income when identifying the automatic stabilization properties of income taxes.

With each wave until 1992 the PSID has used household income and estimates of deductions and exemptions to construct a household's marginal tax rate and tax payments. For exemptions the PSID has recorded the number of dependents used for tax

\footnotetext{
${ }^{1}$ Skinner (1987) used data from the Consumer Expenditure Survey in 1972-1973 to estimate expenditures on various components of consumption and their relation to total consumption. He then used his parameter estimates along with data for the independent variables from the PSID to produce a value of consumption
} 
purposes, and for deductions they have used data from the Internal Revenue Service's Statistics of Income to generate a typical value of itemized deductions for the household's adjusted gross income. Taxable income is then computed by subtracting positive values of excess itemized deductions (itemized deductions less the standard deduction) from gross income for tax years prior to 1987 , or by subtracting the larger of itemized deductions and the standard deduction from gross income for tax years 1987 and beyond. Given taxable income, they then compute tax payments based on the statutory rates for each year. The PSID also computes an estimated value of the EITC for qualifying families such that tax payments are permitted to be negative. However, they omit both Social Security tax payments as well as state income tax payments. We follow Ziliak and Kniesner (1999) to obtain an estimate of total taxes by adding the estimated value of payroll tax payments and a state income tax payment for the household's state of residence based on the state's average income tax rate.

Before turning to estimation issues we present some summary information on our variables of interest in Figure 2 and Table 2. Figure 2 depicts average annual levels of real food consumption, real composite consumption, and real gross family income. We deflate food consumption by the food component of the CPI, and deflate composite consumption and income by the personal consumption expenditure deflator (base 1987). Aside from the two missing years the divergence between average food and average composite consumption is striking. Food accounts for just over 10 percent of the average household's gross income, and composite consumption accounts for just over 80 percent

that is $C_{\mathrm{t}}=110.1+1.418 *$ food $($ home $)+2.604 *$ food $($ away $)+0.0988 *$ house value $+1.538 *$ rent + $2.257 *$ utilities $+624.6 *$ vehicles. 
of gross income. Its much larger budget share means that composite consumption will be more responsive to a given income change than food consumption.

[Figure 2 and Table 2 here]

\section{Estimation Issues}

The complete implicit consumption insurance model in (6) can be estimated consistently using OLS (Cochrane 1991, Deaton 1997, Gertler and Gruber 1997, Mace 1991, Nelson 1994). Introducing household-specific disposable income to capture partial insurance makes estimating the Euler equation in (7) more complicated econometrically. It is unreasonable to assume that $E\left(\Delta y_{d t}^{h} \Delta \varepsilon_{t}^{h}\right)=0$ because the composite error term contains the household-specific discount factor, $\ln \rho^{h}$, which is likely to covary with income over the life cycle. Another complexity we must confront in the econometric setup is that if disposable income is measured with error then it will covary contemporaneously with the error term in consumption.

\section{A. Latent Heterogeneity}

Consider first the case where the evolution of gross income is not independent of the discount factor. Because the model in (7) is in first differences unobserved personspecific time-invariant heterogeneity in consumption levels is swept away. However, growth-rate heterogeneity may manifest itself in the household's discount factor. One approach is to treat the discount factor as a latent person-specific time-invariant effect similar to a model of consumption levels and sweep it out with either the within or the first-difference transformation. A consideration here is that the within transformation renders inconsistent any predetermined variables as instruments (Keane and Runkle 1992), and the first-difference transformation exacerbates measurement errors-in- 
variables problems relative to the within transformation and results in the loss of another year of data (Griliches and Hausman 1986).

An alternative econometric approach is the correlated random-effects estimators of Mundlak (1978), who proposed using the individual's means of the time-varying regressors as proxies for the fixed effect, and Chamberlain (1984), who proposed using the linear projection of the time-varying regressors as proxies for the fixed effect. We use a correlated random-effects approach similar to Mundlak (1978), but instead of using the individual's means of the time-varying regressors we more closely follow the method of Lawrance (1991), who estimates discount rates as a function of pre-sample information. The equation for the discount factor we use is

$$
\ln \rho^{h}=x^{h} \varphi+\omega^{h}
$$

where $x^{h}$ is a vector of pre-sample variables and $\omega^{h}$ is a random error. The variables we use as pre-sample information include the household head's education level, race, and five-year birth cohort, the latter of which are intended to capture cohort-specific differences in discount rates. Our amended estimating equation becomes

$$
\Delta \ln \left(c_{t}^{h} / n_{t}^{h}\right)=\alpha \Delta \ln \left(C_{t}\right)+\beta \Delta \ln \left(y_{d t}^{h}\right)+x^{h} \varphi+\Delta \zeta_{t}^{h},
$$

where $\Delta \zeta_{t}^{h}=\omega^{h}+\Delta \theta_{t}^{h}$.

\section{B. Measurement Error}

Estimation of equation (9) is complicated further by possible measurement error in changes in disposable income. In the case of income changes there are two, possibly offsetting, sources of measurement error. First, there is classical attenuation bias in the coefficient toward zero due to incorrect measurement of the various income components and tax payments. Second, and less common, is the positive bias arising because the 
household's income is used to construct the dependent variable, composite consumption.

It is impossible to determine a priori whether the regression coefficient is likely to be biased upward or downward. ${ }^{2}$

To estimate the model parameters in equation (9) consistently we specify a vector of moment conditions, $E\left(z_{t}^{h} \Delta \zeta_{s}^{h}\right)=0 \forall s \geq t$, whereby a set of predetermined instruments, $z_{t}^{h}$, are assumed available and orthogonal to the contemporaneous error term. ${ }^{3}$ One possible solution to estimating moment conditions is two stage least squares (2SLS). However, as discussed previously, serial correlation is likely problematic both because composite consumption implicitly contains durable goods and because the error term contains random time-invariant heterogeneity, $\omega^{h}$. Consequently, 2SLS will not be efficient. A tractable alternative estimator that permits general forms of serial correlation, both due to unobserved heterogeneity and to the moving average process in $\Delta \zeta_{t}{ }_{t}$, is Keane and Runkle's (1992) forward-filter estimator.

The forward filter estimator, which still maintains orthogonality with the original set of predetermined instruments, is estimated in two steps. First we estimate equation (9) by 2 SLS and save the (T-2) vector of estimated residuals for each household, $\Delta \hat{\zeta}^{h}$. Next, we compute a $(\mathrm{T}-2) \times(\mathrm{T}-2)$ upper-triangular Cholesky decomposition of $\hat{C}=\left(\frac{1}{H} \sum \Delta \hat{\zeta}^{h} \Delta \hat{\zeta}^{h^{\prime}}\right)^{-1}$, followed by premultiplying equation (9) by $\hat{Q}=\left(I_{H} \otimes \hat{C}\right)$.

Finally, we estimate the transformed, forward-filtered equation using the original set of

\footnotetext{
${ }^{2}$ Deaton (1997, p. 381) confronts a similar measurement error problem in his complete consumption insurance tests applied to data from the $\mathrm{C}$ te d'Ivoire.

${ }^{3}$ Following Hayashi et al. (1996), we "balance" the unbalanced data by replacing incalculable changes across years that result from missing person years with zeros. This guarantees positive semi-definiteness of the fourth moments and ensures that the expectation of the moment condition is zero.
} 
instruments. While Hansen's (1982) Generalized Method-of-Moments (GMM) estimator is efficient for this class of problems, recent bootstrap Monte Carlo evidence is that the estimator we use has good finite-sample properties relative to 2SLS and GMM (Ziliak 1997).

\section{Empirical Results}

We begin estimating equation (9) by specifying a base-case model where composite consumption is disposable income net of the change in liquid wealth. The instrument set includes a constant, values at $(t-1)$ of the head's annual hours of work, age, number of children, real hourly wage, the state unemployment rate, and dummies for marital status, health status, spouse's education, geographic region, industry, occupation, union status, home ownership, and female headship, and values at $(t-2)$ of real disposable income. As specification checks on instrument sets we test the validity of the overidentifying restrictions with the Sargan test, and test the exogeneity of selected instruments with a pseudo likelihood-ratio test (Eichenbaum et al. 1988).

In column (1) of Table 3 we report base-case estimates. The estimated coefficient on the change in log disposable income is highly statistically significant, which is consistent with the previous consumption-smoothing literature's rejection of the complete consumption insurance hypothesis. The estimated parameter indicates that, with no offset from income taxation, a 10 percent decrease in gross family income makes composite consumption fall by 9 percent. When evaluated at the overall sample means, the post-tax effect of a 10 percent reduction in gross income is a 7.7 percent reduction in consumption $(0.9067 \times(1-0.316) \times(42240 / 34040))$. On average the progressive federal income tax in 
the 1980s stabilized consumption losses by about 15 percent, which is an underappreciated benefit to households who experience idiosyncratic income losses.

[ Table 3 here ]

The Sargan test reported in the last row of Table 3 indicates that the overidentifying restrictions are satisfied collectively at the 0.04 significance level (in the first-stage 2SLS regression $p=0.67$ ). As an additional specification check on the results in column (1) we test the exogeneity of some of the instruments: the household's head's hours of work at $t-1$ and disposable income at $t-2$. Disposable income at $t-2$ may fail exogeneity if there is sluggish adjustment of consumption changes to past income; hours of work of the head may fail exogeneity if consumption and leisure are not separable in utility, although by including gross income we are implicitly allowing nonseparability between consumption and leisure. Testing for instrument exogeneity involves taking the difference between the restricted and unrestricted Sargan tests, which is distributed as $\chi^{2}(m)$ with degrees of freedom equal to the number of restrictions. Comparing the specification in column (1) with the specifications in columns (2) and (3) indicates that the null hypotheses of exogeneity of hours of work at $(t-1)$ and exogeneity of disposable income at $(t-2)$ of cannot be rejected. Based on tests of instrument validity the specification in column (1) is the preferred model in Table 3.

\section{A. Automatic Stabilization After ERTA and TRA86}

To gauge how the automatic stabilizing component of the income tax has changed because of ERTA and TRA86 we offer some illustrative calculations of the percentage reduction in the effect of gross income changes on consumption changes attributable to income-tax offsets. Holding the tax system constant we examine the impact of income 
cuts of 10 and 30 percent on consumption relative to the impact on consumption that would occur in the absence of the income tax. ${ }^{4}$ We consider tax years 1980, 1982, 1985, and 1987 for a married couple filing jointly with two children and for a female head of household with two children. We also separate the extent of automatic stabilization of consumption with and without FICA and the EITC. To compare households situated similarly in the income distribution we consider representative (married or femaleheaded) households from the Current Population Survey with the median, one-half the median, and 150 percent of the median gross incomes in each year. Finally, we consider a married couple located in the top 5 percent of the income distribution to gauge how the tax system has stabilized the consumption of the wealthy. Table 4 presents our calculations applicable to a 10 or 30 percent cut in gross income evaluated at current $(1980,1982,1985$, or 1987) dollars.

\section{[ Table 4 here]}

The general pattern in Table 4 is a substantial decline in automatic stabilization of consumption with the 1980s tax reforms. For example, the 1980 tax system reduced the impact on consumption of a 10 percent cut in gross income by 13 percent for a married couple with median income. In 1980 if a typical married couple suffered a 10 percent income cut the household fell from the 28 to the 24 percent marginal tax bracket. As of 1987 the household remains in the 15 percent bracket and receives only a 6 percent offset from the income tax system, which is a reduction in stabilization of 55 percent. Comparable (50 percent) declines in tax-reform induced stabilization also appear for

\footnotetext{
${ }^{4}$ For each representative filing unit we apply the standard deduction (which is built into the pre-TRA86 tax tables) and personal exemptions specific to each tax year in calculating taxable income.
} 
married couples with median, 50 percent of median, and 150 percent of median incomes in the face of 30 percent income reductions. ${ }^{5}$

For female-headed households at half the median, the tax system provides no consumption-smoothing benefits for income losses, whereas median income femaleheaded households experiencing 30 percent declines in income face a 100 percent decline in stabilization from 1980 to 1987 . Single mothers at one-half the median income are outside the federal income tax system altogether, while single mothers at the median income experience declines in their marginal tax rate from 14 percent to zero. Although low-income single mothers have access to the transfer system for consumption stabilization, reductions in both the generosity of real transfer payments and in access to programs after passage of the Personal Responsibility and Work Opportunity Reconciliation Act of 1996 makes consumption stabilization less in evidence.

Perhaps surprisingly, our general conclusions do not change much with the inclusion of FICA and the EITC. Although the level of stabilization increases with additional taxes related to income in most circumstances the downward trend in stabilization brought about by the federal income-tax reforms dominates. Exceptions to the trend toward less stabilization of consumption following the tax reforms of the 1980s are female heads at 150 percent of the median income facing 10 percent income cuts and female heads at the median income facing 30 percent cuts. By 1987 single mothers at 150 percent of the median income qualified for the EITC after a 10 percent income decline and in turn experienced a 95 percent increase in post-tax stabilization. In the case of

\footnotetext{
${ }^{5}$ We also did the exercise of Table 4 with in-sample data, which produces comparable results. For the median taxpayer the stabilization effect of the tax system was about 17 percent in both the 1980 and 1982 tax years, but by tax year 1987 the stabilizing effect had fallen to about nine percent, which is about a 47 percent reduction after TRA86.
} 
single mothers at the median income, rather than a 100 percent decline in stabilization there is only a 9 percent decline because of the payroll tax and the EITC. In the 1980s the EITC only affected very low-income households. Married couples with 50 percent of the median income only qualify for the EITC after large income losses, and so that the EITC offered a consumption buffer for a limited subset of households during the 1980s. As discussed below, with the program's expansions in the 1990s the EITC now reaches deeper into the income distribution and is likely playing a more prominent stabilization role.

A possible limitation with using current income in the calculations of Table 4 is that the income distribution should be an endogenous function of the tax system so that a more informative exercise may be to calculate consumption stabilization based on constant dollars (Kasten et al. 1994). In Table 5 we repeat the calculations in Table 4 except that we express income in constant (1985) dollars. A few noticeable differences appear. Low-income married households experienced a doubling of collective insurance once the payroll tax and EITC are included, and female-headed households at 150 percent of the median experienced a more than doubling of stabilization after 30 percent income cuts. However, the overall pattern still emerging is that the tax reforms of the 1980s reduced collective insurance for households.

[Table 5 here]

\section{B. Sensitivity Checks}

Our final econometric activity is to test how our central conclusion that the progressive federal income tax system provides collective insurance benefits to households may depend on econometric details. Table 6 presents the results of six 
sensitivity checks, where for ease of comparison we repeat the base-case estimates of specification (1) of Table 3.

\section{[Table 6 here]}

Smooth Tax Function. Our first robustness check is to replace the tax payments constructed by the PSID staff and used in calculating disposable income with a tax function that is approximated by a smooth cubic polynomial in taxable income. A smooth tax function recommended by MaCurdy et al. (1990) and applied by Ziliak and Kniesner (1999) is an econometrically attractive alternative to the piece-wise linear approach to estimating tax effects of labor supply. In the smooth income tax approach the payroll and average state income tax rates still apply, but the federal rate is a continuously differentiable function. When we use the smooth tax rate function in estimating the Euler equation for consumption the effect of automatic stabilization is virtually unchanged. That the estimates from using a smooth tax function are in accord with the PSID suggests that the taxes computed by the PSID are comparatively well measured.

Aggregate Resources. Equation (9), which we use to examine the separate impacts of ERTA and TRA86 on consumption stabilization, is similar to what researchers use to test the permanent income hypothesis by examining whether households are excessively sensitive to transitory income changes (Hall and Mishkin 1982, Lusardi 1996, Runkle 1991, Zeldes 1989, Ziliak 1998). If we replace aggregate consumption by the after-tax interest rate, and if the after-tax interest rate captures aggregate business cycle conditions, then a non-zero coefficient on income changes indicates excess sensitivity. Tests of partial insurance using (9) are valid to the extent that $C_{t}$ adequately tracks aggregate resources. As a check on the assumption that aggregate consumption 
tracks aggregate resources well we replace average consumption with time dummies in the third column of Table 6. The estimated effect of disposable income changes on consumption changes is little affected by the use of time dummies, lending support to our base-case specification.

Additional Latent Heterogeneity. It is possible that there is still latent heterogeneity in the Euler equations for consumption that we have discussed up to now. For completeness we have estimated the baseline specification in first-difference form, and the result appears in column (4) of Table 6. Allowing for additional person-specific heterogeneity not captured in the covariates lowers the estimated marginal effect of disposable income on consumption by about seven percent, or from about 0.91 to about 0.85. When evaluated at the overall sample means of the data the estimated effect of a 10 percent cut in gross income is to reduce consumption by 7.3 percent, which is about 14.7 percent less than a comparable cut without a stabilizing tax offset. The estimated partial insurance effect of income-based taxation is nearly identical to the base case estimate of 15 percent, which suggests that our correlated random effects specification captures timeinvariant heterogeneity in the evolution of consumption reasonably well.

Income. We have implicitly been aggregating labor, capital, and transfer income as though they receive the same tax treatment, which was generally not the case in the pre-TRA86 system. In another sensitivity check we replace total real family income with only income that is subject to taxation and reconstruct disposable income. When the change in taxable income is the focal regressor, a 10 percent cut in disposable income results in only a 6 percent reduction in consumption. Apparently, greater variability in capital and transfer income make consumption changes less responsive to taxable-income 
changes than to total-income changes. Evaluated at the sample mean values of the marginal tax rate and gross and net incomes, our results using taxable income are that the income tax system reduces by 14 percent the impact of a taxable income change on consumption, which is comparable to our base-case estimate of 15 percent. Our main conclusion is preserved that the tax system continues to provide a substantial tax offset to gross-income changes.

Consumption Measure. The last two checks involve changing our measure of consumption. First, we re-define saving to include changes in home equity when constructing composite consumption. Applying our sample-selection filters results in a loss of an additional 1540 person-years because changes in home valuation are likely subject to considerable measurement error. The impact of changes in gross income on consumption changes is dampened relative to the base case, but the impact of income-tax offset remains strong. One possibility for the observed difference is that when unrealized capital gains in the home are treated as another form of saving one produces a far less accurate characterization of income and consumption.

For completeness we mimic the previous consumption-insurance literature using the PSID and measure consumption with real food expenditures. Although there is evidence of automatic stabilization the coefficient on disposable-income changes is considerably smaller, which is consistent with our prior that the Food Stamp program is the main avenue of insurance for food consumption. In the Euler equation for food consumption there is strong rejection of the overidentifying restrictions, which further implies a need for consumption measures broader than food expenditures when testing the implicit consumption insurance hypothesis. 


\section{Tax Reforms of the 1990s}

It will prove additionally instructive to infer whether and how much the automatic stabilization of consumption changed as a result of the Omnibus Budget Reconciliation Acts of 1990 and 1993 and the Taxpayer Relief Act of 1997. The tax reforms of the 1990s partially reversed the move toward fewer brackets begun with TRA86 in favor of a rate structure more like the 1987 situation. Instead of the two tax brackets in 1988 there were five marginal tax rates of 15, 28, 31, 36, and 39.6 percent by 1998 . At the same time significant expansions of the payroll tax base and rates continued such that by 1998 the applicable base was $\$ 68,400$ with a rate of 7.65 percent. More significant for low-income households was the substantial increase in the generosity of the EITC. From 1987 to 1998 the phase-in rate increased from 14 to 40 percent, the maximum credit increased from $\$ 851$ to $\$ 3756$, and the phase-out rate increased from 10 to 21 percent. Together, the greater number of tax rates, the broader payroll tax base, and the higher EITC subsidy and phase-out rates should make automatic stabilization greater at the end of the 1990s than at the end of the 1980s.

To examine the possibility of increased stabilization of consumption by changes in income-related taxes during the 1990s we conduct an exercise analogous to the income-constant calculations of Table 5 by using our estimated consumption equation with tax system data for tax year 1998. When taken in isolation changes to the federal personal income tax during the 1990s created a slight increase in the income-tax offset for taxpayers facing a large ( 30 percent) negative income shock. Exceptions to the increased stabilization of consumption by the personal income tax are low-income couples and single mothers who have less consumption stabilization because they were 
eliminated from the tax rolls by the more generous standard deduction and personal exemption in 1998. When factoring in the impact of FICA and the EITC there are several instances of greatly increased automatic consumption stabilization. A married couple with the median income that suffers a 30 percent gross income reduction had the shock to consumption reduced by 40 percent in 1998 versus a nine percent reduction 1987 . The reason for the substantial increase in consumption insurance is that the median income married couple now falls into the phase-out range of the EITC and faces a substantially higher marginal tax rate than 10 years ago. Similarly enlarged consumption stabilization during the 1990s appears for married couples at 50 percent of the median income and single mothers at 150 percent of the median income. Interestingly, relatively high-income married couples (the upper 20 percent of the income distribution) also experienced increased consumption insurance against large income losses because of the expanded FICA base. In sum, there has been a restoration or expansion of collective consumption insurance in the federal income-related tax system during the 1990s driven largely by the increased generosity of the EITC.

\section{Conclusion}

We specify a model of partial implicit consumption insurance where the focus is on identifying the degree to which the automatic stabilization of consumption has changed because of ERTA and TRA86. Our data are from the Panel Study of Income Dynamics for interview years 1980-1991, and our measure of consumption is constructed as a residual of income net of taxes and liquid saving. The econometric model treats person-specific discount rates as a correlated random effect, and to control for possible endogenous explanatory variables and serial correlation we use a forward-filter estimator. 
On average, the progressive income tax system stabilizes consumption by about 15 percent in the face of idiosyncratic shocks to income. In some cases tax reforms of the 1980s actually increased the automatic stabilization inherent in a progressive income tax, but the typical outcome is that ERTA and TRA86 reduced composite consumption stability by about 50 percent, even after controlling for changes in FICA and the EITC. More recent tax reforms, most notably increased EITC generosity, have restored or enhanced consumption insurance for certain economic groups such as single mothers and low income married couples.

Our results highlight an under-appreciated benefit to households that is implicit in a progressive income tax. Undoubtedly the deadweight loss from reduced incentives fell for many taxpayers with the 1980s tax reforms. However, there was also a welfare loss from the reduction in collective insurance. An important topic for future research is to evaluate the offsetting welfare gains and losses from static versus dynamic efficiency effects of the 1980s changes in the structure of personal income taxes. 
Table 1: Tax Rate Schedules for Married Taxpayers in Selected Tax Years ${ }^{\mathrm{a}}$

\begin{tabular}{|c|c|c|c|}
\hline \multicolumn{2}{|c|}{1980} & \multicolumn{2}{|c|}{1982} \\
\hline $\begin{array}{c}\text { Taxable Income } \\
(\$ 1000 \mathrm{~s})\end{array}$ & $\begin{array}{c}\text { Marginal Tax } \\
\text { Rate }(\%)\end{array}$ & $\begin{array}{l}\text { Taxable Income } \\
(\$ 1000 \mathrm{~s})\end{array}$ & $\begin{array}{c}\text { Marginal Tax } \\
\text { Rate }(\%)\end{array}$ \\
\hline 3.4 or less & 0 & 3.4 or less & 0 \\
\hline $3.4-5.5$ & 14 & $3.4-5.5$ & 12 \\
\hline $5.5-7.6$ & 16 & $5.5-7.6$ & 14 \\
\hline $7.6-11.9$ & 18 & $7.6-11.9$ & 16 \\
\hline $11.9-16.0$ & 21 & $11.9-16.0$ & 19 \\
\hline $16.0-20.2$ & 24 & $16.0-20.2$ & 22 \\
\hline $20.2-24.6$ & 28 & $20.2-24.6$ & 25 \\
\hline 24.6-29.9 & 32 & $24.6-29.9$ & 29 \\
\hline $29.9-35.2$ & 37 & $29.9-35.2$ & 33 \\
\hline $35.2-45.8$ & 43 & $35.2-45.8$ & 39 \\
\hline $45.8-60.0$ & 49 & $45.8-60.0$ & 44 \\
\hline $60.0-85.6$ & 54 & $60.0-85.6$ & 49 \\
\hline $85.6-109.4$ & 59 & $85.6-109.4$ & 50 \\
\hline $109.4-162.4$ & 64 & $109.4-162.4$ & 50 \\
\hline $162.4-215.4$ & 68 & $162.4-215.4$ & 50 \\
\hline $215.4+$ & 70 & $215.4+$ & 50 \\
\hline \multicolumn{2}{|c|}{1985} & \multicolumn{2}{|c|}{1987} \\
\hline $\begin{array}{c}\text { Taxable Income } \\
(\$ 1000 \mathrm{~s})\end{array}$ & $\begin{array}{c}\text { Marginal Tax } \\
\text { Rate }(\%) \\
\end{array}$ & $\begin{array}{c}\text { Taxable Income } \\
(\$ 1000 \mathrm{~s})\end{array}$ & $\begin{array}{c}\text { Marginal Tax } \\
\text { Rate }(\%) \\
\end{array}$ \\
\hline 3.54 or less & 0 & 3.0 or less & 11 \\
\hline $3.54-5.72$ & 11 & $3.0-28.0$ & 15 \\
\hline $5.72-7.91$ & 12 & $28.0-45.0$ & 28 \\
\hline $7.91-12.39$ & 14 & $45.0-90.0$ & 35 \\
\hline $12.39-16.65$ & 16 & $90.0+$ & 38.5 \\
\hline $16.65-21.02$ & 18 & & \\
\hline $21.02-25.6$ & 22 & & \\
\hline $25.6-31.12$ & 25 & & \\
\hline $31.12-36.63$ & 28 & & \\
\hline $36.63-47.67$ & 33 & & \\
\hline $47.67-62.45$ & 38 & & \\
\hline $62.45-89.09$ & 42 & & \\
\hline 89.09-113.86 & 45 & & \\
\hline $113.86-169.02$ & 49 & & \\
\hline $169.02+$ & 50 & & \\
\hline
\end{tabular}




\begin{tabular}{lcc}
\hline \multicolumn{3}{c}{ Table 2: Selected Summary Statistics } \\
\hline \multicolumn{1}{c}{ Variable } & Sample Mean & Standard Deviation \\
$\Delta \ln ($ Composite Consumption Per Capita) & 0.009 & 0.380 \\
$\Delta \ln ($ Disposable Income) & 0.012 & 0.246 \\
Marginal Tax Rate & 0.316 & 0.099 \\
Gross Income (\$10000s) & 4.224 & 3.293 \\
Disposable Income (\$10000s) & 3.404 & 2.459 \\
White & 0.677 & 0.468 \\
Less than High School & 0.224 & 0.417 \\
High School & 0.369 & 0.483 \\
More than High School & 0.406 & 0.491 \\
Birth Cohort 1 & 0.282 & 0.450 \\
Birth Cohort 2 & 0.273 & 0.446 \\
Birth Cohort 3 & 0.163 & 0.370 \\
Birth Cohort 4 & 0.133 & 0.339 \\
Birth Cohort 5 & 0.149 & 0.356 \\
\hline
\end{tabular}




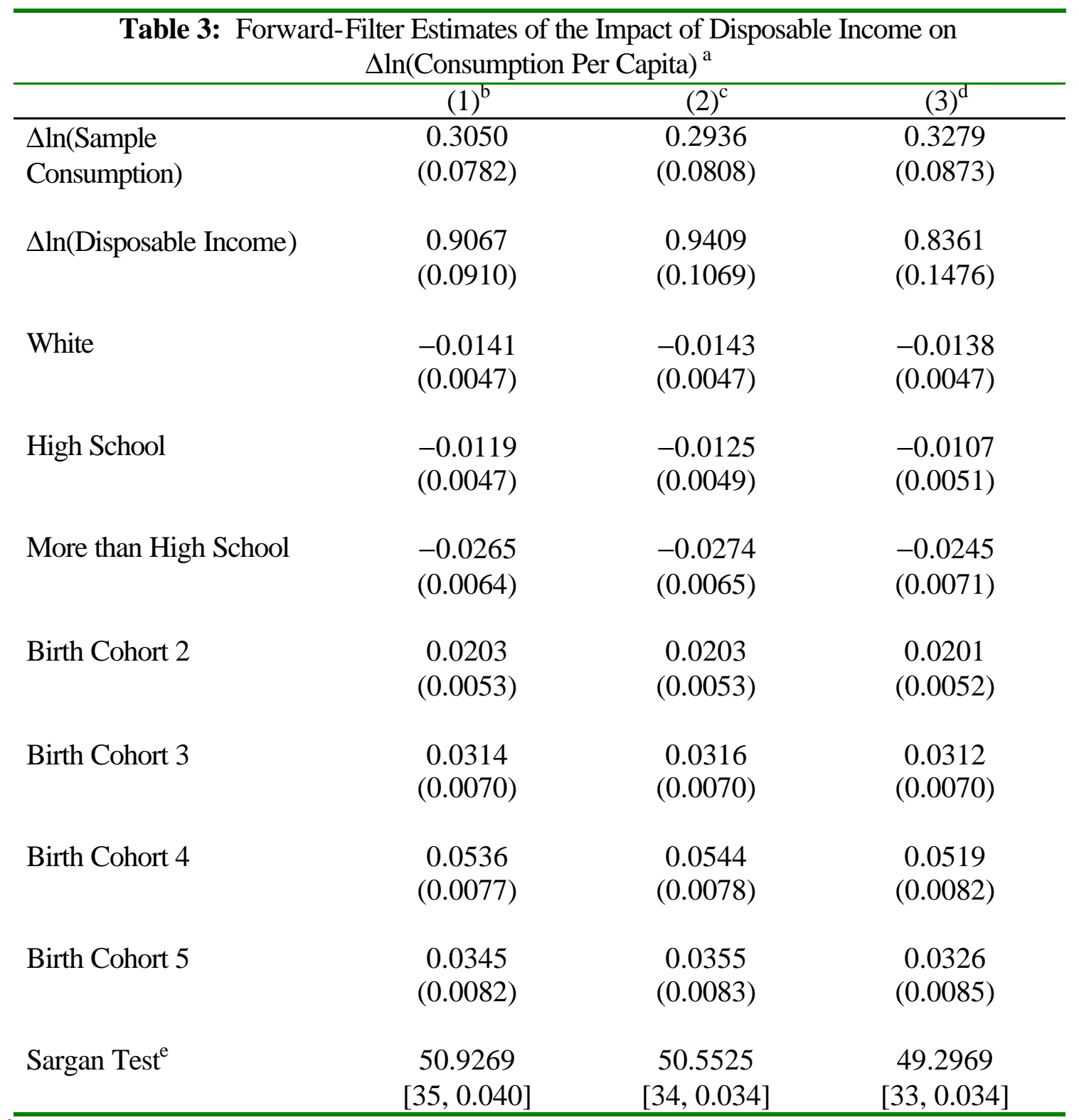

${ }^{\mathrm{a}}$ Heteroskedasticity and autocorrelation-consistent standard errors are in parentheses. NT $=11043$.

${ }^{\mathrm{b}}$ The instrument set includes a constant, $(t-1)$ values of head's annual hours of work, age of head, the number of children, the head's real hourly wage, state unemployment rate, dummies for marital status, health status, spouse's education, geographic region, industry, occupation, union status, female head, and home ownership, along with $(t-2)$ values of real disposable income.

${ }^{\mathrm{c}}$ Specification (1) instruments without $(t-2)$ values of real disposable income.

${ }^{\mathrm{d}}$ Specification (2) instruments without $(t-1)$ head's annual hours of work.

${ }^{\mathrm{e}}$ The Sargan Test is a test of the validity of the overidentifying restrictions, with degrees of freedom and $p$-value given in square brackets. 


\begin{tabular}{|c|c|c|c|c|c|c|c|}
\hline \multicolumn{8}{|c|}{$\begin{array}{c}\text { Table 4: Extent of Automatic Stabilization of Consumption } \\
\text { For Alternative Tax Years and Tax Filing Status } \\
\text { (Inclusive of FICA and the Earned Income Tax Credit) }^{\mathrm{a}}\end{array}$} \\
\hline \multicolumn{8}{|c|}{10 Percent Cut in Gross Income (Current \$'s) } \\
\hline \multirow{3}{*}{$\begin{array}{l}\text { Tax Year } \\
1980\end{array}$} & \multicolumn{4}{|c|}{ Married Couple with 2 Children } & \multicolumn{3}{|c|}{ Female Head with 2 Children } \\
\hline & $\begin{array}{l}50 \% \text { of } \\
\text { Median }\end{array}$ & Median & $\begin{array}{l}150 \% \text { of } \\
\text { Median }\end{array}$ & Top 5\% & $\begin{array}{l}50 \% \text { of } \\
\text { Median }\end{array}$ & Median & $\begin{array}{l}150 \% \text { of } \\
\text { Median } \\
\end{array}$ \\
\hline & $\begin{array}{c}11.76 \\
(12.57)\end{array}$ & $\begin{array}{c}13.22 \\
(14.21)\end{array}$ & $\begin{array}{c}17.22 \\
(12.05)\end{array}$ & $\begin{array}{c}24.76 \\
(21.20)\end{array}$ & $\begin{array}{r}0.00 \\
(0.00)\end{array}$ & $\begin{array}{c}12.21 \\
(30.05)\end{array}$ & $\begin{array}{c}10.34 \\
(11.08)\end{array}$ \\
\hline 1982 & $\begin{array}{c}11.15 \\
(11.99)\end{array}$ & $\begin{array}{c}14.31 \\
(15.50)\end{array}$ & $\begin{array}{c}18.35 \\
(12.11)\end{array}$ & $\begin{array}{c}25.34 \\
(21.20)\end{array}$ & $\begin{array}{r}0.00 \\
(0.00)\end{array}$ & $\begin{array}{c}8.08 \\
(25.26)\end{array}$ & $\begin{array}{r}8.63 \\
(9.31)\end{array}$ \\
\hline 1985 & $\begin{array}{r}8.59 \\
(9.25)\end{array}$ & $\begin{array}{c}11.34 \\
(12.32)\end{array}$ & $\begin{array}{c}18.95 \\
(12.26)\end{array}$ & $\begin{array}{c}18.95 \\
(14.20)\end{array}$ & $\begin{array}{r}0.00 \\
(0.00)\end{array}$ & $\begin{array}{c}7.89 \\
(24.54)\end{array}$ & $\begin{array}{c}9.94 \\
(10.76)\end{array}$ \\
\hline 1987 & $\begin{array}{c}11.31 \\
(12.22)\end{array}$ & $\begin{array}{r}5.99 \\
(6.51)\end{array}$ & $\begin{array}{l}16.14 \\
(9.50)\end{array}$ & $\begin{array}{c}18.60 \\
(13.97)\end{array}$ & $\begin{array}{r}0.00 \\
(0.00)\end{array}$ & $\begin{array}{c}9.06 \\
(24.99)\end{array}$ & $\begin{array}{r}9.29 \\
(21.66)\end{array}$ \\
\hline \multicolumn{8}{|c|}{30 Percent Cut in Gross Income (Current \$’s) } \\
\hline & \multicolumn{4}{|c|}{ Married Couple with 2 Children } & \multicolumn{3}{|c|}{ Female Head with 2 Children } \\
\hline & $\begin{array}{l}50 \% \text { of } \\
\text { Median }\end{array}$ & Median & $\begin{array}{l}150 \% \text { of } \\
\text { Median }\end{array}$ & Top 5\% & $\begin{array}{l}50 \% \text { of } \\
\text { Median }\end{array}$ & Median & $\begin{array}{l}150 \% \text { of } \\
\text { Median }\end{array}$ \\
\hline $\begin{array}{l}\text { Tax Year } \\
1980\end{array}$ & $\begin{array}{c}12.39 \\
(28.49)\end{array}$ & $\begin{array}{c}12.57 \\
(13.49)\end{array}$ & $\begin{array}{c}15.99 \\
(17.23)\end{array}$ & $\begin{array}{c}21.83 \\
(17.31)\end{array}$ & $\begin{array}{r}0.00 \\
(0.00)\end{array}$ & $\begin{array}{c}12.71 \\
(20.79)\end{array}$ & $\begin{array}{c}10.65 \\
(26.92)\end{array}$ \\
\hline 1982 & $\begin{array}{c}11.48 \\
(26.96)\end{array}$ & $\begin{array}{c}10.24 \\
(11.06)\end{array}$ & $\begin{array}{c}17.13 \\
(18.59)\end{array}$ & $\begin{array}{c}23.39 \\
(18.17)\end{array}$ & $\begin{array}{r}0.00 \\
(0.00)\end{array}$ & $\begin{array}{c}10.34 \\
(30.44)\end{array}$ & $\begin{array}{r}8.84 \\
(24.47)\end{array}$ \\
\hline 1985 & $\begin{array}{c}8.57 \\
(10.17)\end{array}$ & $\begin{array}{c}9.32 \\
(10.11)\end{array}$ & $\begin{array}{c}12.93 \\
(14.09)\end{array}$ & $\begin{array}{c}16.79 \\
(10.75)\end{array}$ & $\begin{array}{r}0.00 \\
(0.00)\end{array}$ & $\begin{array}{c}8.81 \\
(28.39)\end{array}$ & $\begin{array}{r}8.83 \\
(23.96)\end{array}$ \\
\hline 1987 & $\begin{array}{c}9.68 \\
(23.87)\end{array}$ & $\begin{array}{r}7.58 \\
(8.22)\end{array}$ & $\begin{array}{r}5.18 \\
(5.63)\end{array}$ & $\begin{array}{c}22.71 \\
(17.27)\end{array}$ & $\begin{array}{r}0.00 \\
(0.00)\end{array}$ & $\begin{array}{c}0.00 \\
(18.97)\end{array}$ & $\begin{array}{c}11.64 \\
(26.23)\end{array}$ \\
\hline
\end{tabular}

\footnotetext{
${ }^{\mathrm{a}}$ The numbers in the table reflect the percentage reduction from the no-tax case in the effect of gross income changes on consumption changes due to marginal tax rates and tax payments. Each representative filing unit is assumed to take the standard deduction and personal exemptions in calculating taxable income.
} 


\section{Table 5: Extent of Automatic Stabilization of Consumption For Alternative Tax Years and Tax Filing Status (Inclusive of FICA and the Earned Income Tax Credit) $^{\mathrm{a}}$}

10 Percent Cut in Gross Income (\$1985)

\begin{tabular}{|c|c|c|c|c|c|c|c|}
\hline \multirow{3}{*}{$\begin{array}{l}\text { Tax Year } \\
1980\end{array}$} & \multicolumn{4}{|c|}{ Married Couple with 2 Children } & \multicolumn{3}{|c|}{ Female Head with 2 Children } \\
\hline & $\begin{array}{l}50 \% \text { of } \\
\text { Median }\end{array}$ & Median & $\begin{array}{l}150 \% \text { of } \\
\text { Median }\end{array}$ & Top 5\% & $\begin{array}{l}50 \% \text { of } \\
\text { Median }\end{array}$ & Median & $\begin{array}{l}150 \% \text { of } \\
\text { Median }\end{array}$ \\
\hline & $\begin{array}{c}11.08 \\
(11.86)\end{array}$ & $\begin{array}{l}14.56 \\
(8.52)\end{array}$ & $\begin{array}{c}26.26 \\
(22.55)\end{array}$ & $\begin{array}{c}27.49 \\
(24.67)\end{array}$ & $\begin{array}{r}0.00 \\
(0.00)\end{array}$ & $\begin{array}{c}11.71 \\
(27.02)\end{array}$ & $\begin{array}{c}14.01 \\
(15.05)\end{array}$ \\
\hline 1982 & $\begin{array}{c}10.62 \\
(11.44)\end{array}$ & $\begin{array}{c}13.65 \\
(14.80)\end{array}$ & $\begin{array}{c}24.91 \\
(19.44)\end{array}$ & $\begin{array}{c}24.33 \\
(20.30)\end{array}$ & $\begin{array}{r}0.00 \\
(0.00)\end{array}$ & $\begin{array}{c}9.68 \\
(26.36)\end{array}$ & $\begin{array}{c}12.38 \\
(13.36)\end{array}$ \\
\hline 1985 & $\begin{array}{r}8.56 \\
(9.25)\end{array}$ & $\begin{array}{c}11.34 \\
(12.32)\end{array}$ & $\begin{array}{c}18.95 \\
(12.26)\end{array}$ & $\begin{array}{c}18.95 \\
(14.20)\end{array}$ & $\begin{array}{r}0.00 \\
(0.00)\end{array}$ & $\begin{array}{c}7.89 \\
(24.54)\end{array}$ & $\begin{array}{c}9.94 \\
(10.76)\end{array}$ \\
\hline 1987 & $\begin{array}{c}12.05 \\
(24.29)\end{array}$ & $\begin{array}{r}6.41 \\
(6.96)\end{array}$ & $\begin{array}{c}17.13 \\
(10.13)\end{array}$ & $\begin{array}{c}19.71 \\
(14.85)\end{array}$ & $\begin{array}{r}0.00 \\
(0.00)\end{array}$ & $\begin{array}{c}9.66 \\
(26.36)\end{array}$ & $\begin{array}{c}9.91 \\
(22.90)\end{array}$ \\
\hline
\end{tabular}

30 Percent Cut in Gross Income $(\$ 1985)$

\begin{tabular}{|c|c|c|c|c|c|c|c|}
\hline \multirow[b]{3}{*}{$\begin{array}{l}\text { Tax Year } \\
1980\end{array}$} & \multicolumn{4}{|c|}{ Married Couple with 2 Children } & \multicolumn{3}{|c|}{ Female Head with 2 Children } \\
\hline & $\begin{array}{l}50 \% \text { of } \\
\text { Median }\end{array}$ & Median & $\begin{array}{l}150 \% \text { of } \\
\text { Median }\end{array}$ & Top 5\% & $\begin{array}{l}50 \% \text { of } \\
\text { Median } \\
\end{array}$ & Median & $\begin{array}{l}150 \% \text { of } \\
\text { Median }\end{array}$ \\
\hline & $\begin{array}{c}11.62 \\
(12.42)\end{array}$ & $\begin{array}{c}13.06 \\
(14.04)\end{array}$ & $\begin{array}{c}17.02 \\
(19.84)\end{array}$ & $\begin{array}{c}24.50 \\
(20.96)\end{array}$ & $\begin{array}{r}0.00 \\
(0.00)\end{array}$ & $\begin{array}{c}12.06 \\
(29.77)\end{array}$ & $\begin{array}{c}10.21 \\
(10.94)\end{array}$ \\
\hline 1982 & $\begin{array}{c}10.94 \\
(11.75)\end{array}$ & $\begin{array}{c}13.04 \\
(14.09)\end{array}$ & $\begin{array}{c}21.09 \\
(22.89)\end{array}$ & $\begin{array}{c}22.43 \\
(17.38)\end{array}$ & $\begin{array}{r}0.00 \\
(0.00)\end{array}$ & $\begin{array}{c}9.85 \\
(29.30)\end{array}$ & $\begin{array}{c}10.46 \\
(25.69)\end{array}$ \\
\hline 1985 & $\begin{array}{r}8.57 \\
(9.24)\end{array}$ & $\begin{array}{c}9.32 \\
(10.11)\end{array}$ & $\begin{array}{c}12.93 \\
(14.09)\end{array}$ & $\begin{array}{c}16.79 \\
(10.75)\end{array}$ & $\begin{array}{r}0.00 \\
(0.00)\end{array}$ & $\begin{array}{c}8.81 \\
(28.40)\end{array}$ & $\begin{array}{c}8.83 \\
(23.96)\end{array}$ \\
\hline 1987 & $\begin{array}{c}10.32 \\
(24.33)\end{array}$ & $\begin{array}{r}8.09 \\
(8.77)\end{array}$ & $\begin{array}{r}5.54 \\
(6.02)\end{array}$ & $\begin{array}{l}15.35 \\
(9.00)\end{array}$ & $\begin{array}{r}0.00 \\
(0.00)\end{array}$ & $\begin{array}{c}0.00 \\
(20.09)\end{array}$ & $\begin{array}{c}12.39 \\
(27.64)\end{array}$ \\
\hline
\end{tabular}

\footnotetext{
${ }^{\mathrm{a}}$ The numbers in the table reflect the percentage reduction from the no-tax case in the effect of gross income changes on consumption changes due to marginal tax rates and tax payments. Each representative filing unit is assumed to take the standard deduction and personal exemptions in calculating taxable income.
} 


\begin{tabular}{|c|c|c|c|c|c|c|c|}
\hline \multicolumn{8}{|c|}{$\begin{array}{l}\text { Table 6: Sensitivity of the Effect of Disposable Income Changes on } \\
\text { Log Per Capita Consumption Changes to Alternative Specifications }{ }^{\text {a }}\end{array}$} \\
\hline & Base Case $^{b}$ & $\begin{array}{l}\text { Smooth } \\
\text { MTR }^{c}\end{array}$ & $\begin{array}{c}\text { Time } \\
\text { Dummies }^{\mathrm{d}}\end{array}$ & $\begin{array}{c}\text { First } \\
\text { Difference }\end{array}$ & $\begin{array}{l}\text { Taxable } \\
\text { Income }^{\text {f }}\end{array}$ & $\begin{array}{l}\text { Home } \\
\text { Equity }^{\mathrm{g}}\end{array}$ & Food $^{\mathrm{h}}$ \\
\hline $\begin{array}{l}\Delta \ln (\text { Disposable } \\
\text { Income) }\end{array}$ & $\begin{array}{c}0.9067 \\
(0.0910)\end{array}$ & $\begin{array}{c}0.8844 \\
(0.0898)\end{array}$ & $\begin{array}{c}0.9193 \\
(0.0923)\end{array}$ & $\begin{array}{c}0.8537 \\
(0.1456)\end{array}$ & $\begin{array}{c}0.6074 \\
(0.0797)\end{array}$ & $\begin{array}{c}0.6308 \\
(0.1305)\end{array}$ & $\begin{array}{c}0.2722 \\
(0.0826)\end{array}$ \\
\hline Sargan Test ${ }^{\mathrm{h}}$ & $\begin{array}{c}50.9269 \\
{[35,0.040]}\end{array}$ & $\begin{array}{c}52.9925 \\
{[35,0.026]}\end{array}$ & $\begin{array}{c}45.2889 \\
{[35,0.114]}\end{array}$ & $\begin{array}{c}45.2889 \\
{[35,0.114]}\end{array}$ & $\begin{array}{c}64.2018 \\
{[35,0.002]}\end{array}$ & $\begin{array}{c}75.9747 \\
{[35,0.000]}\end{array}$ & $\begin{array}{c}117.7213 \\
{[35,0.000]}\end{array}$ \\
\hline $\begin{array}{l}\text { a Heteroskedastic } \\
{ }^{\mathrm{a}} \text { The base case } \mathrm{r} \\
{ }^{\mathrm{b}} \text { The marginal tax } \\
{ }^{\mathrm{c}} \text { Time dummies } \\
{ }^{\mathrm{d}} \text { Model in equati } \\
{ }^{\mathrm{e}} \text { Gross income on } \\
{ }^{\mathrm{f}} \text { Groving is define } \\
{ }^{\mathrm{g}} \text { Saving Composite con } \\
{ }^{\mathrm{h}} \text { The Sargan Test } \\
p \text {-values given in }\end{array}$ & $\begin{array}{l}\text { Ind autocorrela } \\
\text { to Specificatic } \\
\text { e is approximat } \\
\text { ised as covaria } \\
7 \text { ) is estimated i } \\
\text { ccludes househ } \\
\text { oadly to incluc } \\
\text { ption is replace } \\
\text { test of the valic }\end{array}$ & $\begin{array}{l}\text { n-consistent } \\
\text { (1) of Table } 3 \text {. } \\
\text { by smooth, ct } \\
\text { in place of th } \\
\text { first difference } \\
\text { d income subj } \\
\text { changes in ho } \\
\text { by food const } \\
\text { y of the overi } \\
\text { notes to Table }\end{array}$ & $\begin{array}{l}\text { dard errors ar } \\
\text { polynomial in } \\
\text { mple average } \\
v T=9315 \text {. } \\
\text { to taxation. } N \\
\text { equity in cons } \\
\text { tion. } N T=9,8 \\
\text { ifying restrict }\end{array}$ & $\begin{array}{l}\text { iven in parent } \\
\text { xable income. } \\
\text { consumption. } \\
10,610 \text {. } \\
\text { cting composit } \\
\text { ss with degrees }\end{array}$ & nsumption & $9,503$. & \\
\hline
\end{tabular}




\section{References}

Altug, S. and R. Miller (1990). "Household Choice in Equilibrium," Econometrica 58:3, 543-570.

Attanasio, O. and S. Davis (1996). "Relative Wage Movements and the Distribution of Consumption," Journal of Political Economy 104:6, 1227-1262.

Attanasio, O. and G. Weber (1995). "Is Consumption Growth Consistent with Intertemporal Optimization? Evidence from the Consumer Expenditure Survey," Journal of Political Economy 103:6, 1121-1157.

Auerbach, A. (1996). “Tax Reform, Capital Allocation, Efficiency, and Growth,” in. H. Aaron and W. Gale, eds., Economic Effects of Fundamental Tax Reform, Washington, D.C.: The Brookings Institution, 29-81.

Auerbach, A. and J. Slemrod (1997). "The Economic Effects of the Tax Reform Act of 1986," Journal of Economic Literature 35:2, 589-632.

Auerbach, A. and D. Feenberg (1999). "The Significance of Federal Taxes as Automatic Stabilizers," forthcoming in the Journal of Economic Perspectives.

Banks, J., R. Blundell, and A. Brugiavini (1997). "Risk Pooling, Precautionary Saving, and Consumption Growth," Institute for Fiscal Studies Working Paper.

Bernheim, B. (1999). “Taxation and Saving," National Bureau of Economic Research Working Paper 7061.

Bosworth, B. and G. Burtless (1992). "Effects of Tax Reform on Labor Supply, Saving, and Investment," Journal of Economic Perspectives 6:1, 3-26.

Blundell, R., A. Duncan, and C. Meghir (1998). "Estimating Labor Supply Responses Using Tax Reforms," Econometrica 66:4, 827-862.

Burman, L., W. Gale, and D. Weiner (1998). "Six Tax Laws Later: How Individuals' Marginal Tax Rates Changed Between 1980 and 1995," National Tax Journal $51: 3,637-652$.

Chamberlain, G. (1984). "Panel Data," in Z. Griliches and M. Intriligator, eds., Handbook of Econometrics Vol. II, 1247-1318.

Cochrane, J. (1991). “A Simple Test of Consumption Insurance," Journal of Political Economy 99:5, 957-976. 
Cohen, D., and G. Follette (1999). “The Automatic Fiscal Stabilizers: Quietly Doing Their Thing," Division of Research and Statistics, Federal Reserve Board, Washington, DC.

Deaton, A. (1997). The Analysis of Household Surveys: A Microeconometric Approach to Development Policy, Baltimore: Johns Hopkins University Press.

Diamond, P. (1998). "Optimal Income Taxation: An Example with a U-Shaped Pattern of Optimal Marginal Tax Rates," American Economic Review 88:1, 83-95.

Dynarski, S. and J. Gruber (1997). “Can Families Smooth Variable Earnings?” Brookings Papers on Economic Activity 1, 229-284.

Eichenbaum, M., L. Hansen, and K. Singleton (1988). "A Time Series Analysis of Representative Agent Models of Consumption and Leisure Choice under Uncertainty." The Quarterly Journal of Economics 103(1), 51-78.

Eissa, N. (1996). "Taxation and the Labor Supply of Married Women: The Tax Reform Act of 1986 as a Natural Experiment,” NBER Working Paper No. 5023.

Engen, E. and W. Gale (1996). "The Effects of Fundamental Tax Reform on Saving," in. H. Aaron and W. Gale, eds., Economic Effects of Fundamental Tax Reform, Washington, D.C.: The Brookings Institution, 83-121.

Gertler, P. and J. Gruber (1997). "Insuring Consumption Against Illness,” NBER Working Paper No. 6035.

Griliches, Z., and J. Hausman (1986). "Errors in Variables in Panel Data,” Journal of Econometrics 31, 93-118.

Gruber, J. (1996). "Cash Welfare as a Consumption Smoothing Mechanism for Single Mothers," NBER Working Paper No. 5738.

Gruber, J. (1997). "The Consumption Smoothing Benefits of Unemployment Insurance," The American Economic Review 87:1, 192-205.

Hamermesh, D. (1982). "Social Insurance and Consumption: An Empirical Inquiry," The American Economic Review 72:1, 101-113.

Hansen, L. (1982). "Large Sample Properties of Generalized Method-of-Moments Estimators," Econometrica 50(3), 1029-1054.

Hausman, J. (1986). "Labor Supply," in H. Aaron and J. Pechman, eds., How Taxes Affect Economic Behavior, Washington D.C.: The Brookings Institution, 27-72. 
Hayashi, F. (1985). “The Permanent Income Hypothesis and Consumption Durability: Analysis Based on Japanese Panel Data," Quarterly Journal of Economics 100:4, 1083-1113.

Hayashi, F., J. Altonji, and L. Kotlikoff (1996). "Risk Sharing Between and Within Families," Econometrica 64:2, 261-294.

Hsiao, C. (1986). Analysis of Panel Data, Cambridge: Cambridge University Press.

Kasten, R., F. Sammartino, and E. Toder (1994). “Trends in Federal Tax Progressivity, 1980-93," in J. Slemrod, ed., Tax Progressivity and Income Inequality, Cambridge: Cambridge University Press, 9-58.

Keane, M. and D. Runkle (1992). "On the Estimation of Panel-Data Models with Serial Correlation When Instruments are not Strictly Exogenous," Journal of Business and Economic Statistics 10:1, 1-9.

Kniesner, T. and J. Ziliak (1998). The Effects of Recent Tax Reforms on Labor Supply, Washington, D.C.: American Enterprise Institute for Public Policy Research.

Lawrance, E. (1991). "Poverty and the Rate of Time Preference," Journal of Political Economy 99:1, 54-77.

Mace, B. (1991). "Full Insurance in the Presence of Aggregate Uncertainty," Journal of Political Economy 99:5, 928-956.

MaCurdy, T., D. Green, and H. Paarsch (1990). “Assessing Empirical Approaches for Analyzing Taxes and Labor Supply,” Journal of Human Resources 25, 415-489.

Morduch, J. (1995). "Income Smoothing and Consumption Smoothing," Journal of Economic Perspectives 9:3, 103-114.

Mudlak, Y. (1978). "On the Pooling of Time Series and Cross Section Data," Econometrica 46, 69-85.

Nelson, J. (1994). "On Testing Full Insurance Using Consumer Expenditure Survey Data," Journal of Political Economy 102:2, 384-394.

Skinner, J. (1987). "A Superior Measure of Consumption from the Panel Study of Income Dynamics," Economics Letters 23:2, 213-216.

Stiglitz, J. (1987). "Pareto Efficient and Optimal Taxation and the New Welfare Economics," in A. Auerbach and M Feldstein, eds., Handbook of Public Economics, Vol. 2, Amsterdam: North Holland. 
Strawczynski, M. (1998). "Social Insurance and the Optimum Piecewise Linear Income Tax," Journal of Public Economics 69, 371-388.

Townsend, R. (1994). “Risk and Insurance in Village India,” Econometrica 62:3, 539_ 592.

Varian, H. (1980). "Redistributive Taxation as Social Insurance," Journal of Public Economics 14:1, 49-68.

Ziliak, J. (1997). "Efficient Estimation with Panel Data when Instruments are Predetermined: An Empirical Comparison of Moment-Condition Estimators," Journal of Business and Economic Statistics 15, 419-431.

Ziliak, J. (1998). "Does the Choice of Consumption Measure Matter? An Application to the Permanent-Income Hypothesis," Journal of Monetary Economics 41:1, 201-216.

Ziliak, J. and T. Kniesner (1999). "Estimating Life-Cycle Labor Supply Tax Effects," Journal of Political Economy 107:2, 326-359. 
Figure 1: Statutory Federal Marginal Tax Rates for Married Couples Filing Jointly

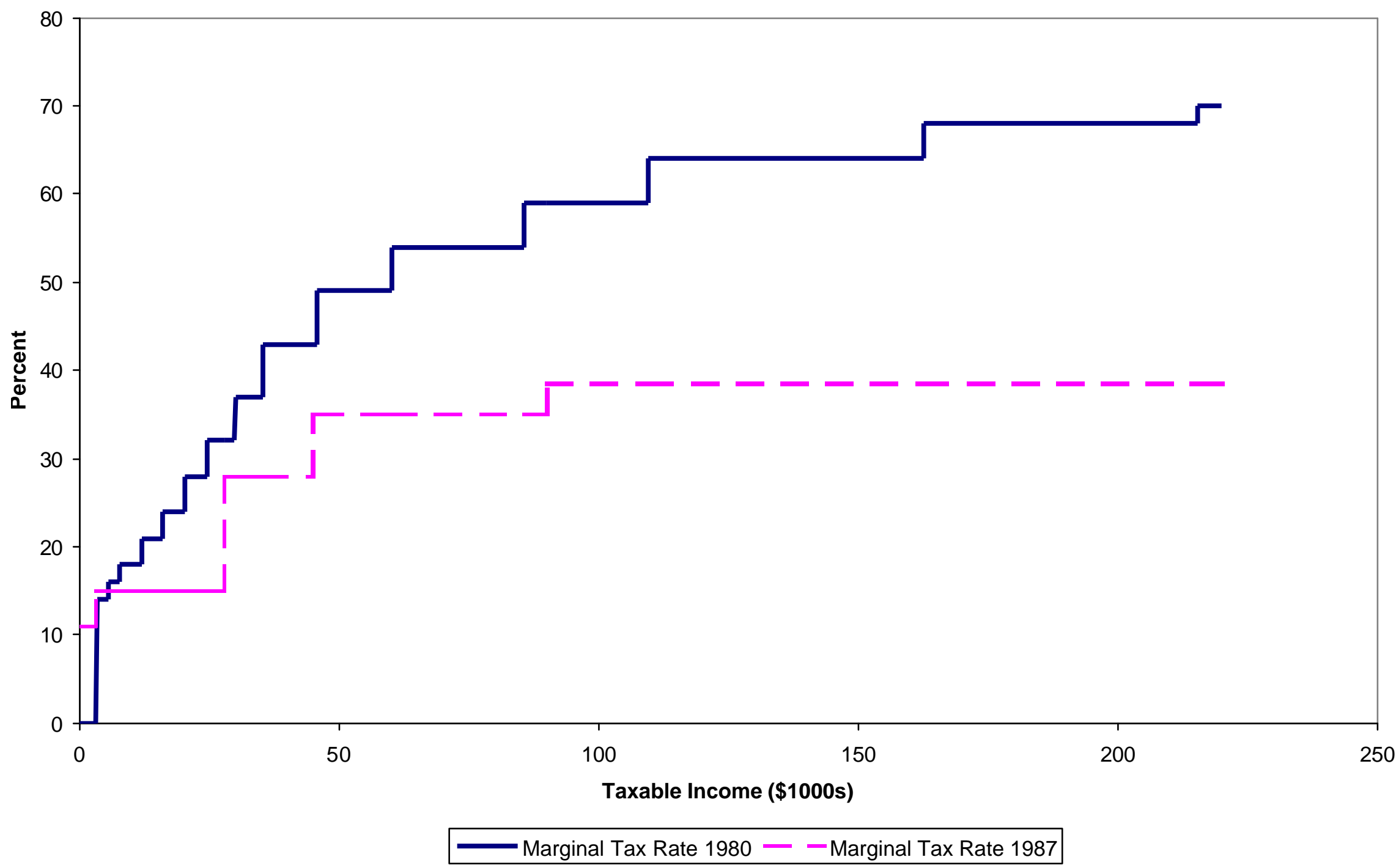


Figure 2: Levels of Consumption and Income, 1980-1990

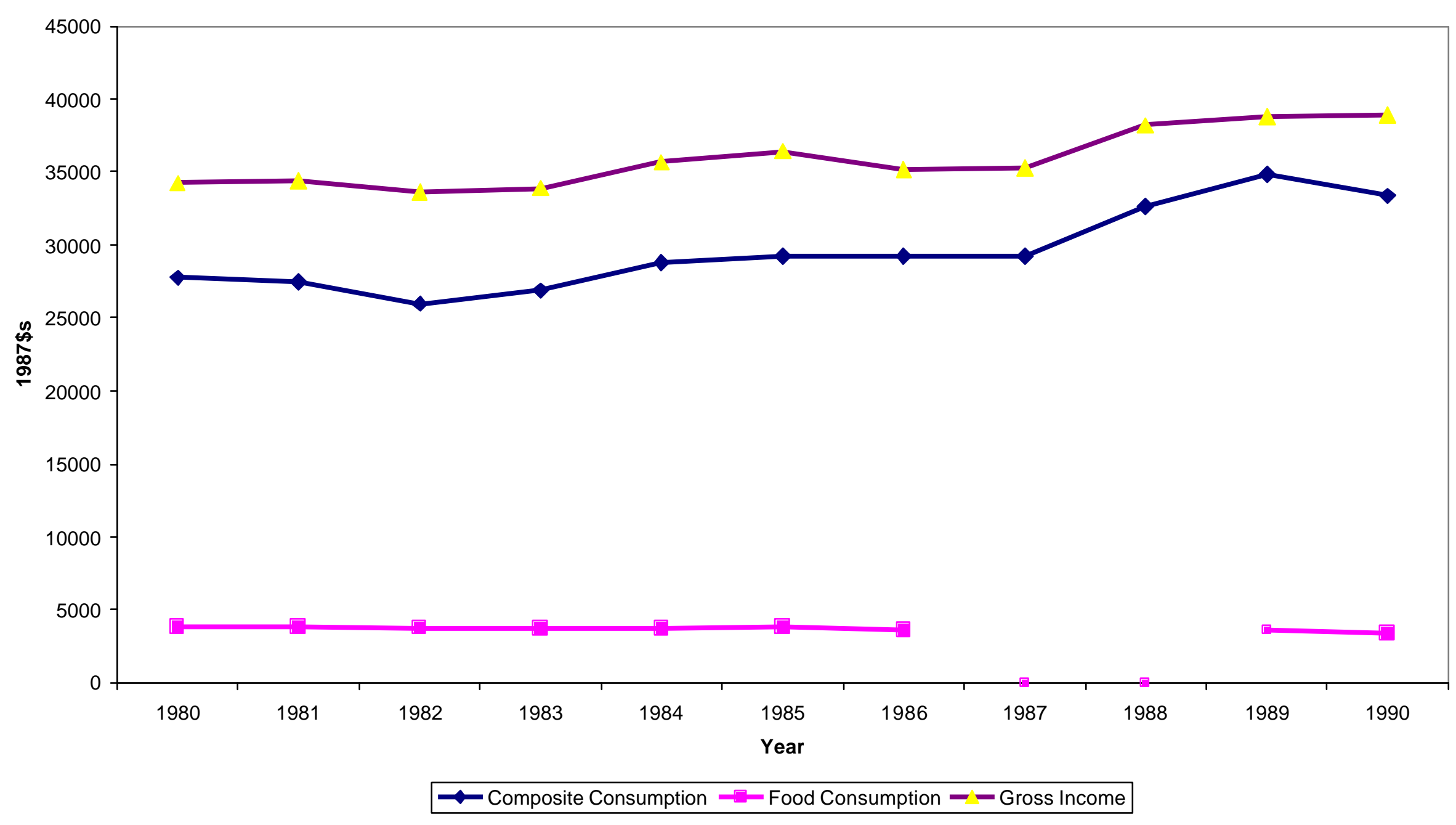


